\title{
IMPLEMENTASI ELECTRONIC GOVERNANCE MELALUI APLIKASI LAYANAN ASPIRASI DAN PENGADUAN ONLINE RAKYAT DI KABUPATEN KARAWANG
}

\author{
Praditha Yaniarti Eka Pratiwi \\ Mahasiswa Ilmu Pemerintahan \\ Fakultas Ilmu Sosial dan Ilmu Politik \\ Universitas Singaperbangsa Karawang \\ dditha71@gmail.com \\ Mayasari \\ Dosen Ilmu Komunikasi \\ Fakultas Ilmu Sosial dan Ilmu Politik \\ Universitas Singaperbangsa Karawang \\ Mayasari.kurniawan@unsika.ac.id \\ Kariena Febriantin \\ Dosen Ilmu Pemerintahan \\ Fakultas Ilmu Sosial dan Ilmu Politik \\ Universitas Singaperbangsa Karawang \\ Kariena.febriantin@gmail.com
}

\begin{abstract}
ABSTRAK
Langkah pemerintah dalam mewujudkan kepemerintahan yang baik atau Good Governance yaitu dengan menerapkan sistem Electronic Governance. Electronic Governance ialah penggunaan teknologi informasi oleh pemerintah untuk memberikan informasi dan pelayanan bagi warganya. Selain itu penggunaan teknologi informasi dan komunikasi juga memiliki perkembangan yang cukup luas, berpengaruh dengan kehidupan sehari-hari sehingga tidak dapat dipisahkan, serta banyak diterapkan dalam berbagai bidang kehidupan manusia, termasuk dalam praktik pemerintahan. Bentuk wujud dari Electronic Governance yang dibuat oleh pemerintah adalah sebuah aplikasi bernama Layanan Aspirasi dan Pengaduan Online Rakyat (LAPOR) yang digunakan sebagai wadah bagi masyarakat Indonesia khususnya masyarakat Kabupaten Karawang dalam menyampaikan keluhan dan aspirasinya. Penelitian ini bertujuan untuk mengetahui bagaimana implementasi dan penerapan Electronic Governance di Kabupaten Karawang. Teknik pengumpulan data yang digunakan dalam penelitian ini adalah observasi, wawancara dan dokumentasi. Metode yang digunakan dalam penelitian ini yaitu menggunakan metode deskriptif, selanjutnya kajian ini dilakukan dengan menggunakan pendekatan kualitatif yang difokuskan pada upaya yang dilakukan oleh lembaga/instansi di Kabupaten Karawang dalam mengimplementasikan sistem Electronic Governance.
\end{abstract}

Kata Kunci: Electronic Governance, Implementasi, Pemerintah. 
78 |Pratiwi, Mayasari, Febriantin Implementasi Electronic Governance...

\section{Pendahuluan}

Penggunaan teknologi informasi dan komunikasi atau Information and Communication Technology (ICT) telah semakin luas. Penggunaan ICT dapat mencakup berbagai macam bidang, seperti bidang perdagangan, pendidikan, pertahanan dan keamanan negara, sosial dan sebagainya. ICT memiliki kelebihan yaitu dalam hal kecepatan, kemudahan, biaya yang lebih murah, sentralisasi data dan akses data yang bisa digunakan untuk segala kalangan (Advisor, 2001). Dengan kelebihan-kelebihan tersebut ICT dapat mewujudkan efisiensi dalam gerak kehidupan manusia dalam berinteraksi dengan sesamanya. Oleh karena itu ICT banyak diterapkan dalam berbagai bidang kehidupan manusia, termasuk dalam praktik pemerintahan. Satu diantara manfaat dari penggunaan ICT di bidang pemerintahan yaitu untuk meningkatkan interaksi antara pemerintah dan warga (Sorin, 2003). Seiring dengan perkembangan kepemerintahan yang baik atau Good Governance, KEMENPANRB bersama Dinas Komunikasi dan Informatika Kabupaten Karawang dalam tata kelola dan pelaksanaan pemerintahannya telah bergeser dari good government ke arah Good Governance. Good Governance adalah kepemerintahan yang mengembangkan dan menerapkan prinsip-prinsip profesionalitas, akuntanbilitas, transparansi, demokrasi, pelayanan prima, efesiensi, , supremasi hukum dan dapat diterima oleh seluruh masyarakat (2000). Apabila pemerintah melalui bentuk-bentuk pelayanannya mampu menciptakan suasana yang kondusif dengan masyarakat aka kondisi semacam itu dapat dikategorikan sebagai keadaan yang mengarah pada terselanggarannya asas-asas Good Governance. Sebagai wujud upaya pemerintah dalam menerapkan Good Governance dan menerapkan Electronic Governance, pemerintah menciptakan program aplikasi online bernama Layanan Aspirasi dan Pengaduan Online Rakyat atau disingkat "LAPOR" yang 
telah diciptakan sejak tahun 2013, LAPOR merupakan sistem aplikasi elektronik berbasis media sosial dengan menerapkan sistem yang sederhana, cepat, tepat, tuntas, dan terkoordinasi dengan baik. Aplikasi ini juga merupakan sarana dalam menyampaikan keluhannya baik mengenai keluhan birokrasi, sosial, infrastruktur, dan lain-lain. Hal ini dapat dilakukan masyarakat melalui website yang tersedia yaitu www.lapor.go.id, SMS ke 1708, twitter dengan akun @LAPOR1708, serta melalui aplikasi yang tersedia di sistem Android dan IOS (sumber: www.lapor.go.id). Produk hukum pemerintah membuat inovasi tersebut ialah terkandung di dalam Peraturan Presiden Nomor 76 Tahun 2013 tentang Pengelolaan Pengaduan Pelayanan Publik serta Peraturan Menteri Pendayagunaan Aparatur Negara dan Reformasi Birokrasi Nomor 3 Tahun 2015 tentang Road Map Pengembangan Sistem Pengelolaan Pengaduan Pelayanan Publik Nasional. Adapun grafik dan penjelasan jumlah laporan yang masuk pada tahun 2018 dan 2019 di Kabupaten Karawang.

Gambar 1. Grafik Laporan Masuk melalui Aplikasi Layanan Aspirasi dan Pengaduan Online Rakyat (LAPOR) di Kabupaten Karawang pada tahun 2018

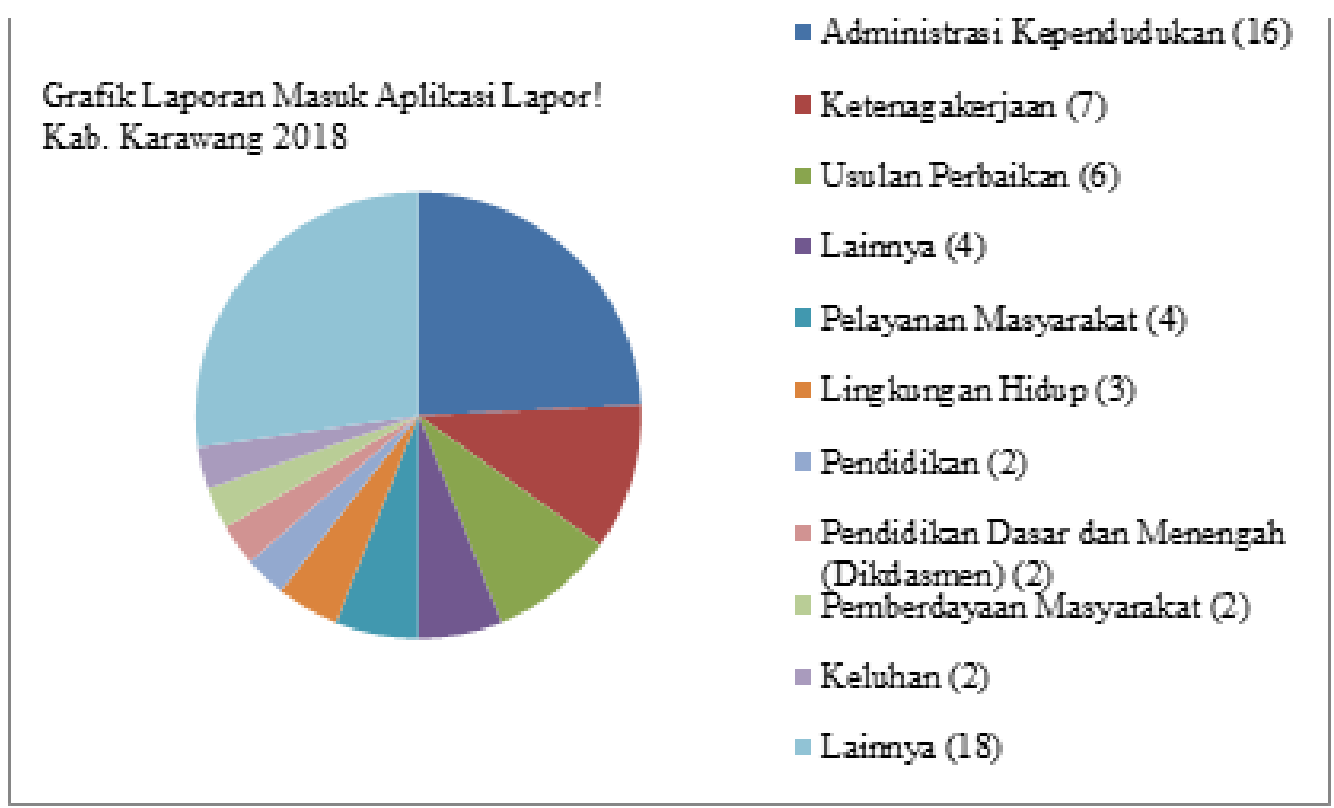

Sumber: Dinas Komunikasi dan Informatika Kabupaten Karawang. 
80 Pratiwi, Mayasari, Febriantin Implementasi Electronic Governance...

Dari gambar tersebut dapat dijelaskan bahwa terdapat berbagai macam katagori bidang yang sering dilaporkan oleh masyarakat Kabupaten Karawang per-Januari 2018 dengan total laporan yaitu sebanyak 66 laporan yang terdiri dari berbagai macam kategori, seperti Administrasi Kependudukan (16), Ketenagakerjaan (7), Usulan Perbaikan (6), Lainnya (4), Pelayanan Masyarakat (4), Lingkungan Hidup (3), Pendidikan (2), Pendidikan Dasar dan Menengah (2), Pemberdayaan Masyarakat (2), Keluhan (2), dan Lainnya (18).

Selanjutnya berdasarkan data Dinas Komunikasi dan Informatika Kabupaten Karawang pelapor di tahun 2019 mengalami peningkatan, hal ini dapat di lihat dari grafik berikut:

\section{Gambar 2. Grafik Laporan Masuk melalui Aplikasi Layanan Aspirasi dan Pengaduan Online Rakyat (LAPOR) di Kabupaten Karawang pada tahun 2019}

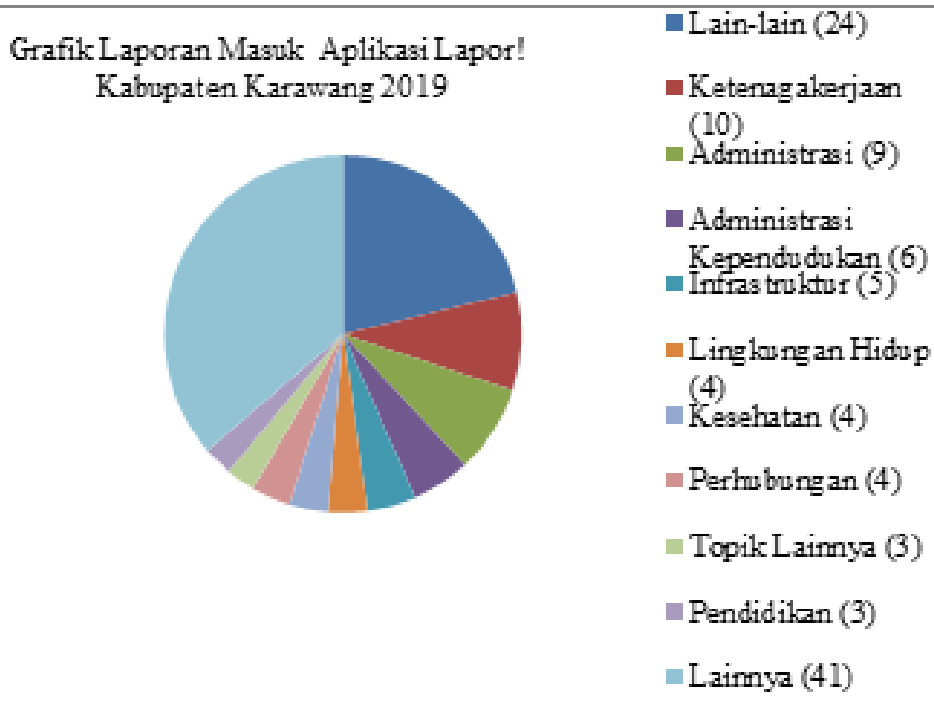

Sumber: Dinas Komunikasi dan Informatika Kabupaten Karawang.

Berdasarkan gambar tersebut dapat dijelaskan bahwa terdapat sejumlah pelapor per Januari 2019, dengan total laporan sebanyak 113 laporan yang terdiri dari kategori Lain-lain (24), Ketenagakerjaan (10), Administrasi (9), Administrasi Kependudukan (6), Infrastruktur (5), Lingkungan Hidup (4), Kesehatan (4), Perhubungan (4), Topik Lainnya (3), Pendidikan (3), dan 
Lainnya (41). Dengan ini artinya laporan yang masuk melalui aplikasi Layanan Aspirasi dan Pengaduan Online Rakyat (LAPOR) pada tahun 2018-2019 mengalami peningkatan.

Permasalahan lain pun muncul, yang di mana meskipun produk hukum sudah tersedia, program aplikasi ini sudah berjalan cukup lama dan laporan yang masuk dari tahun 2018-2019 mengalami peningkatan akan tetapi masih terdapat permasalahan dalam pengimplementasiannya seperti tidak tepatnya kurun waktu penyelesaian laporan, kurangnya kegiatan sosialisasi kepada masyarakat serta kurangnya kuantitas sumber daya manusia yang tersedia di Dinas Komunikasi dan Informatika Kabupaten Karawang.

\section{Tinjauan Pustaka}

Penelitian (Siti Wedharetno Mursalim) mengenai kajian Implementasi Manajemen Pengaduan Ssitem Layanan Aspirasi dan Pengaduan Online Rakyat (LAPOR) di Kota Bandung, yaitu (1) Hasil assesment menggunakan teori Tjiptono mencakup Komitmen, Visible, Accessible, Kesederhanaan, Kecepatan, Fairness, Confidential, Records, Sumber daya dan Remedy. (2) Pengelolaan sistem LAPOR! di Dinas Komunikasi dan Informatika Pemerintahan Kota Bandung belum tersosialisasi secara merata di kalangan masyarakat sendiri dilihat dari masih banyaknya masyarakat yang belum menggunakan aplikasi LAPOR!, dengan kurangnya kegiatan sosialisasi (output) dapat menyebabkan kurangnya efektivitas penerapan dan implementasi yang baik atau sesuai dengan tujuan yang di tentukan sejak awal (input).

Penelitian (Suci Sitoresmi) mengenai Efektivitas Sistem Informasi Layanan Aspirasi dan Pengaduan Online Rakyat (LAPOR!) Pada Unit Kerja Presiden Bidang Pengawasan dan Pengendalian Pembangunan (UKP4), yaitu (1) Menggunakan dimensi DeLone and McLean, 2003 yaitu Kompnenen dari kesuksesan sistem informasi mempunyai enak dimensi, yaitu kualitas sistem, kualitas informasi, kualitas pelayanan, penggunaan, kepuasan pengguna, dan keuntungan profit (McLean, 2003) (2) Rendahnya pelayanan publik yang dilakukan tanpa menerapkan system online dan upaya meningkatkan pelayanan berdasarkan peraturan yang ada. (3) Sebagai alat ukur penerpan 
dimensi yang jelaskan oleh DeLone and McLean, 2003. Dimensi penggunaan menunjukkan skala sangat efektif, sedangkan pada dimensi kualitas pelayanan menunjukkan hasil cukup efektif.

\section{Electronic Governance}

Electronic Governance adalah penggunaan teknologi informasi khususnya internet, untuk memberikan layanan publik dengan cara yang jauh lebih nyaman, berorientasi pelanggan, hemat biaya, dan semuanya berbeda dan lebih baik secara bersamaan (Holmes, 2004)

Electronic Governance merupakan konsep yang dilakukan pemerintah (baik di tingkat Pemerintah Pusat maupun Pemerintah Daerah) dalam melibatkan partisipasi masyarakat dengan menggunakan teknologi informasi dan komunikasi dalam rangka mengoptimalisasi proses pelayanan publik yang efisien, efektif, transparan dan akuntabel. Dengan memanfaatkan internet, maka akan muncul sangat banyak pengembangan modus layanan dari pemerintah kepada masyarakat yang dapat memungkinkan meningkatkan peran aktif masyarakat dalam melakukan pengaduan pelayanan publik. Tujuan Electronic Governance adalah untuk meningkatkan akses warga negara terhadap pelayanan publik atau pemerintah, meningkatkan akses masyarakat ke sumber-sumber informasi yang dimiliki pemerintah, menangani keluhan masyarakat dan juga persamaan kualitas layanan yang diharapkan oleh seluruh warga negara.

\section{Pengaduan Masyarakat}

Masyarakat yang tidak puas akan pelayanan akan mengeluh tentang pelayanan yang mereka terima. Keluhan itu sendiri perlu ditanggapi dengan cermat oleh organisasi, apakah keluhan tersebut memang bersifat membangun atau hanya ekspresi ketidakpuasan yang tidak membangun untuk perbaikan pelayanan. Keluhan publik merupakan ungkapan yang disebabkan oleh adanya ketidakpuasan publik atas suatu produk atau suatu pelayanan. Meski demikian tidak setiap ketidakpuasan akan diungkap dengan suatu keluhan. Pelanggan akan mengungkapkan keluhan manakala merasa bahwa keluhan yang disampaikan mendapatkan tanggapan yang positif dan tidak banyak menyita waktu serta biaya. Sebaliknya jika mekanisme penanganan keluhan tidak praktis, pelanggan akan lebih memilih untuk tidak mengungkapkan 
keluhannya. Dalam menyampaikan keluhannya, masyarakat memiliki beberapa pilihan dalam melakukan pengaduan, tergantung dari masyarakat yang melakukan pengaduan dan organisasi yang diadukan. Apapun media yang dipilih oleh masyarakat, pada intinya hal tersebut merupakan masukan dari masyarakat yang kurang puas akan pelayanan yang mereka terima. Best \& Sigh, menyebutkan bahwa saluran penyampaian keluhan dan tuntutan biasanya dilakukan melalui tiga jalur, yaitu:

Secara Langsung yaitu Pengaduan langsung dilakukan oleh pelanggan atau publik yang melakukan transaksi dan merasakan ketidakpuasan. Penyampaian secara langsung ini biasanya dilakukan atas transaksi yang penanganan perbaikannya dapat dilakukan saat itu, dan keluhan dapat langsung diterima oleh pihak yang berkewenangan melakukan perbaikan.

Melalui Media Massa yaitu dilakukan jika pelanggan atau publik yang tidak puas, kesulitan bertemu langsung dengan pihak yang berwenang melakukan perbaikan ataupun bila mereka merasa keluhannya tidak ditanggapi secara memadai. Jadi lebih merupakan pelarian atau ungkapan kejengkelan atas ketidakpuasan.

Melalui Pihak Ketiga, Pihak ketiga yang dimaksud disini adalah individu atau lembaga diluar publik atau pelanggan yang tidak merasakan langsung ketidakpuasan. Jalur ketiga ini memiliki efek yang sangat kuat terhadap organisasi yang menjadi sasaran keluhan.

Dalam Peraturan Presiden Nomor 76 Tahun 2013 tentang Pengelolaan Pengaduan Pelayanan Publik yang mengatur Sistem Pengelolaan Pengaduan Pelayanan Publik Nasional (SP4N) merupakan bagian dari sistem informasi pelayanan publik secara nasional yang dapat merealisasikan kebijakan "no wrong door policy" dalam menjamin hak masyarakat untuk menyampaikan pengaduan atas kinerja pelayanan publik. Pelayanan publik sebagai pemberian layanan (melayani) keperluan orang atau masyarakat yang mempunyai kepentingan pada organisasi itu sesuai dengan aturan pokok dan tata cara yang telah ditetapkan. Terbentuknya SP4N diharapkan dapat menjawab tantangan koordinasi dan sinkronisasi pengelolaan pengaduan di berbagai institusi di Indonesia, yang tidak hanya menyediakan sarana pengaduan, tetapi termasuk pengelolaan pengaduan serta tindakan korektif atas penanganan dan penyelesaian pengaduan. Dalam Peraturan Menteri Pendayagunaan Aparatur Negara dan Reformasi Birokrasi (MENPANPRB) Nomor 16 Tahun 2014 Tentang 
84 Pratiwi, Mayasari, Febriantin Implementasi Electronic Governance...

Pedoman Survei Kepuasan Masyarakat Terhadap Penyelenggaraan Pelayanan Publik menjelaskan bahwa pengelolaan pengaduan menjadi salah satu prosedur yang harus dilakukan pada setiap penyelenggaraan pelayanan yang nantinya akan disusun kedalam suatu survey kepuasan masyarakat sehingga pada tahun 2015 Kementerian Pendayagunaan Aparatur Negara dan Reformasi Birokrasi membuat sebuah produk hukum baru yaitu Peraturan Menteri Pendayagunaan Aparatur Negara dan Reformasi Birokrasi Nomor 3 Tahun 2015 tentang Road Map Pengembangan Sistem Pengelolaan Pengaduan Pelayanan Publik Nasional yang digunakan untuk mengatur sistem pengelolaan pengaduan pelayanan publik yang bersifat nasional.

Berdasarkan uraian di atas dapat disimpulkan bahwa pengaduan masyarakat merupakan aspirasi yang disampaikan oleh masyarakat baik perorangan maupun kelompokyang berisi keluhan atas ketidakpuasan pelayanan/kebijakan/penyimpangan yang didapatkan, hal ini dilakukan dengan harapan agar keluhan masyarakat di dengar dan dapat ditindaklanjuti aduannya, karena bagaimanapun pengaduan masyarakat juga merupakan elemen penting bagi instansi pusat atau daerah karena pengaduan yang disampaikan bertujuan untuk memperbaiki kekurangan dari kegiatan yang dilaksanakan.

\section{Media Baru}

Media baru merupakan pengistilahan untuk menggambarkan karakteristik media yang berbeda dari yang telah ada selama ini seperti televise, radio, majalah, koran, yang digolongkan menjadi media lama (old media), sedangkan internet yang mengandung muatan intraktif digolongkan sebagai media baru (new media), dengan adanya istilah baru ini bukan berarti media lam telah hilang dan digantikan dengan media baru, namun ini merupakan pengistilahan untuk menggambarkan karakteristik yang muncul saja (Errika, 2011:70-71). Menurut McQuail (2016), ciri utama media baru ialah adanya keterhubungan akses terhadap khalayak individu sebagai penerima maupun pengirim pesan, interaktivisnya, kegunaan yang beragam sebagai karakter yang terbuka dan sifatnya yang ada dimana-mana. Kategori dari media baru terdiri dari:

1. Interaktif

Media baru diakui paling interaktif meskipun di media lama sudah banyak yang dapat bersifat dua arah seperti kuis, ngobrol, dan sebagainya dengan 
penonton dirumah tetapi itu tetap melaui tahap seleksi atau gatekeeping dari media tersebut.

2. Hipertekstual

Setiap informasi yang sudah ada di media lama seperti televise, radio, dan surat kabar kembali dimasukkan ke dalam media baru. Hal ini digunakan sebagai database perpindahan media dari media lama ke media baru sehingga informasi yang dahulu tidak hilang begitu saja.

3. Jaringan

Jaringan di dalam media baru internet terdapat beberapa jaringan yang saling menguatkan untuk mempermudah orang menemukan dan menggunakan internet dalam mencari informasi. Jaringan-jaringan ini antara lain adalah The World Wide Web (WWW), website perusahaan/negara/pejabat, website edukasi, situs media sosial, blog networks, forum online dan sebagainya. Jaringan ini memperkuat media baru dan juga menjadi salah satu kunci dari media baru.

\section{Dunia maya}

Karakteristik ini menjadi karakteristik yang melenahkan bagi media baru internet, karena sifatnya yang 'maya' sehingga identitas seseorang atau kelompok di dalam media baru internet ini menjadi tidak jelas dan tidak bisa dipercaya sepenuhnya. Proses gatekeeping yang bebas mengakibatkan hal ini menjadi masalah bagi media baru internet.

\section{Simulasi}

Di zaman digital sekarang ini memiliki hubungan yang dekat dengan peniruan atau simulasi. Media baru menirukan beberapa dari media lama yang masih bisa diangkat dimasukkan ke dalam media baru. Khalayak pengguna media baru juga akan meniru apa informasi yang dia dapat di dalam media baru ke dunia nyata yang mempermudah hidupnya.

6. Digital

Di dalam dunia digital semua diproses menggunakan mesin yang di gerakkan oleh sistem informasi yang diolah oleh kode atau nomor yang dibuat oleh manusia. Dalam hal ini media komunikasi dan representasi biasanya terbentuk dari suara dan cahaya yang telah diberi kode dalam suatu sistem. Seperti foto yang dulunya analog menjadi foto digital, dan sebagainya. Kode- 
kode inilah yang kemudian dimasukkan kedalam sebuah memori digital yang digunakan sebagai database.

Media baru adalah media komunikasi yang mengacu pada 'konten' yang bisa diakses kapan saja, dimana saja, pada setiap perangkat digital serta memiliki kemampuan untuk dilakukannya interaksi antara pemberi informasi dan penerima informasi, dan dimungkinkannya partisipasi kreatif dari berbagai pihak. Hal tersebut tentu sangat berbeda dengn pengertian media massa yang berusaha menyebar informasi secara serentak ke berbagai kalangan, namun tidak dimungkinkannya partisipasi dari pihak lain selain sumber yang menyalurkan informasi. Teknologi dari media baru akan selalu memanfaatkan keunggulan dari digitalisasi, kemampuan untuk memanipulasi dan melalui jaringan yang padat serta kompresible dan interaktif (Bruno Schivnki dan Darius Dabrowski, 2014)

\section{Layanan Aspirasi dan Pengaduan Online Rakyat (LAPOR)}

Pengelolaan pengaduan pelayanan publik di setiap organisasi penyelenggara di Indonesia belum terkelola secara efektif dan terintegrasi. Masing-masing organisasi penyelenggara mengelola pengaduan secara parsial dan tidak terkoordinir dengan baik. Akibatnya terjadi duplikasi penanganan pengaduan, atau bahkan bisa terjadi suatu pengaduan tidak ditangani oleh satupun organisasi penyelenggara, dengan alasan pengaduan bukan kewenangannya.

Oleh karena itu, untuk mencapai visi dalam good governance maka perlu untuk mengintegrasikan sistem pengelolaan pengaduan pelayanan publik dalam satu pintu. Tujuannya, masyarakat memiliki satu saluran pengaduan secara Nasional. Untuk itu Pemerintah Republik Indonesia membentuk Sistem Pengelolaan Pengaduan Pelayanan Publik Nasional (SP4N) - Layanan Aspirasi dan Pengaduan Online Rakyat (LAPOR) adalah layanan penyampaian semua aspirasi dan pengaduan masyarakat Indonesia melalui beberapa kanal pengaduan yaitu website www.lapor.go.id, Short Massage Service atau SMS ke 1708, twitter dengan nama akun @lapor1708 serta aplikasi Android dan IOS. SP4N-LAPOR! dibentuk untuk merealisasikan kebijakan "no wrong door policy" yang menjamin hak masyarakat agar pengaduan dari manapun dan jenis apapun akan disalurkan kepada penyelenggara pelayanan publik yang berwenang menanganinya. SP4N bertujuan agar penyelenggara dapat mengelola pengaduan dari masyarakat secara sederhana, cepat, tepat, tuntas, 
dan terkoordinasi dengan baik; Penyelenggara memberikan akses untuk partisipasi masyarakat dalam menyampaikan pengaduan dan meningkatkan kualitas pelayanan publik. SP4N-LAPOR! telah terhubung dengan 34 Kementerian, 96 Lembaga, dan 493 Pemerintah daerah di Indonesia. Jumlah pelapor per Januari 2019 adalah sebanyak 801.257 pengguna. Total laporan yang telah masuk sebanyak 1.389.891. Sumber laporan terbanyak melalui website diikuti oleh Short Massage Service atau SMS, twitter dan aplikasi mobile.

Gambar 3. Jumlah pengguna aplikasi LAPOR per-Januari 2019.

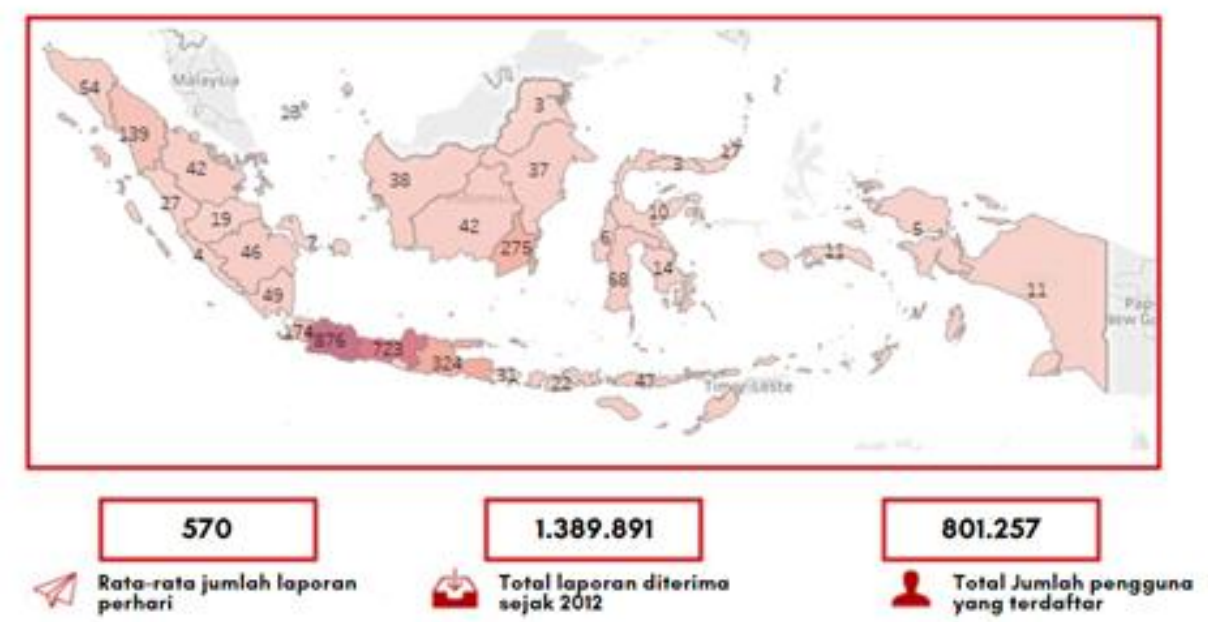

Sumber: https://www.lapor.go.id/tentang, diakses pada tanggal 12/02/2020

Fitur-fitur yang ada dalam aplikasi LAPOR yaitu:

1. Anonim: Fitur yang bisa dipilih oleh pelapor yang akan membuat identitas pelapor tidak akan diketahui oleh pihak terlapor dan masyarakat umum.

2. Rahasia: Seluruh isi laporan tidak dapat dilihat oleh publik.

3. Tracking id: Nomor unik yang berguna untuk meninjau proses tindak lanjut laporan yang disampaikan oleh masyarakat.

\section{Metode Penelitian}

Jenis penelitian ini ialah penelitian dengan metode kualitatif yaitu nilai yang tidak dapat diynatakan dalam angka-angka (statistik). Jadi, data 
88 Pratiwi, Mayasari, Febriantin Implementasi Electronic Governance...

kualitatif adalah data yang berupa kata atau kalimat, gambar, skema yang belum diangkakan. Penelitian yang menggunakan data yang bukan dalam skala rasio, tetapi dalam bentuk skala yang lebih, yaitu skala nominal, ordinal ataupun interval yang kesemuanya dapat dikategorikan, sehingga jelas apa yang akan disamakan dan dibedakan untuk menjawab permasalahan yang telah dirumuskan dalam penelitian (Pasolong, 2014).

Kemudian yang digunakan pada penelitian ini adalah dengan teknik analisis deskriptif, yaitu suatu penelitian yang mendeskripsikan apa yang terjadi di lapangan. Pada penelitian ini terdapat upaya mendeskripsikan, mencatat, menganalisa dan menginterpretasikan kondisi-kondisi yang sekarang ini terjadi atau ada. Penelitian ini tidak menguji hipotesa, melainkan hanya mendeskripsikan informasi apa adanya secara objektif. Oleh karena itu penelitian deskriptif pada umumnya menggunakan kata tanya "bagaimana" dalam merumuskan kalimat pertanyaan penelitiannya (Pasolong, 2014). Lokasi penelitian ini ialah di Kabupaten Karawang dan dilaksanakan di lembaga/instansi terkait yang akan diteliti.

\section{Pembahasan}

\section{Implementasi Aplikasi Layanan Aspirasi dan Pengaduan Online Rakyat (LAPOR) di Kabupaten Karawang}

Dalam rangka pelaksanaan aplikasi LAPOR yang lebih efektif dan juga mengimplementasikannya salah satu misi Dinas Komunikasi dan Informatika Kabupaten Karawang yaitu meningkatkan pengembangan infrastruktur Teknologi Informasi dan komunikasi (TIK) melalui pengembangan aplikasi, muatan layanan informasi publik, standarisasi dan pemanfaatan TIK serta keamanan informasi dan persandian dalam rangka optimalisasi pelayanan informasi publik. Hal tersebut dilaksanakan berdasarkan pada Peraturan Daerah Nomor 16 Tahun 2018 tentang Penyelenggara Sistem Pemerintah 
Berbasis Elektronik (SPBE), dimana seperti yang sudah dijelaskan sebelumnya bahwa dari proses masuknya laporan masyarakat karawang lalu penindaklanjutan laporan hingga laporan itu selesai, proses tersebut dilaksanakan di Dinas Komunikasi dan Informatika sebagai Admin Instansi yang bertugas dalam pelaksana pengelolaan pengaduan pelayanan publik di pemerintah daerah yang ditugaskan oleh pembina/penanggung jawab untuk mengelola pengaduan pelayanan publik

melalui aplikasi SP4N-LAPOR di Kabupaten Karawang. Maka untuk menganalisa seberapa efektif pelaksanaan program tersebut, dalam penelitian ini, peneliti menggunakan teori dari Duncan yang dikutip Steers (1985:53) yang difokuskan pada tiga (3) ukuran yaitu Pencapaian Tujuan terdiri dari beberapa faktor yaitu Standar dan prosedur pengelolaan pengaduan, Pentahapan pengelolaan pengaduan, dan Tindak lanjut dan kurun waktu penyelesaian masalah. Selanjutnya ialah Integrasi yang terdiri dari dua indikator yaitu Sosialisasi program aplikasi LAPOR, dan Koordinasi dan komunikasi instansi terkait pengaduan masyarakat. Lalu yang terakhir ialah Adaptasi merupakan kemampuan organisasi untuk menyesuaikan diri dengan lingkungannya, dan memiliki dua indikator yaitu Jumlah pegawai yang terlibat dalam pengelolaan pengaduan masyarakat dalam semua proses, dan Kemampuan atau kualitas pegawai yang terlibat dalam pengelolaan pengaduan masyarakat dalam semua proses. Dari ketiga ukuran dan indikator tersebut peneliti bisa melihat sejauh mana pemerintah menjalankan pelaksanaan aplikasi LAPOR untuk mencapai tujuan dan sasaran yang direncanakan. Maka peneliti melakukan penelitian ke lapangan dan dari hasil penelitian akan dijelaskan dengan rinci di bawah ini.

\subsection{Pencapaian Tujuan dalam Pelaksanaan Aplikasi LAPOR di Kabupaten Karawang}

Masyarakat selalu menginginkan pelayanan publik yang berkualitas meskipun terkadang keinginan masyarakat akan pelayanan yang berkualitas tidak sesuai dengan yang mereka harapkan hingga secara empiris di dalam pelayanan publik terjadi maladministrasi, pelayanan yang terbelit-belit, melelahkan, dan lamban. Sehingga dengan demikian Indonesia perlu memanfaatkan kehadiran teknologi, informasi dan komunikasi pada tatanan kepemerintahannya dengan tujuan untuk mengefektifkan dan mengefesiensikan pelaksanaan tugas 
pemerintah serta pemberian pelayanan kepada masyarakat. Bagi beberapa masyarakat yang pernah berurusan dengan birokrasi dalam mendapatkan pelayanan publik tentu terkadang pernah mengalami kekecewaan terhadap pelayanan yang mereka dapatkan, dan merasa bingung untuk menyampaikan keluhan atau aspirasinya. Hal inilah yang memunculkan ketidakpuasan masyarakat terhadap pelayanan yang diberikan oleh pemerintah, bentuk kekecewaan tersebut pasti sering dijumpai di berbagai daerah termasuk di Kabupaten Karawang dengan berbagai permasalahan seperti permasalahan di pelayanan pembuatan E-KTP, pelayanan BPJS, tak hanya tentang 'pelayanan' saja tetapi permasalahan jalanan rusak yang mengganggu kegiatan masyarakat, jembatan ambruk dan lain sebagainya pun masih terjadi di Kabupaten Karawang. Masyarakat Karawang terkadang bingung kemana mereka bisa menyampaikan keluhannya bahkan melaporkan kejadian yang tidak mereka harapkan ini baik dalam bentuk kritik maupun saran terhadap instansi yang terkait. Dengan menerapkan aplikasi LAPOR di Kabupaten Karawang di harapkan masyarakat dapat menyampaikan keluhannya dan aspirasinya melalui kanal LAPOR yang tersedia.

\subsubsection{Standar dan prosedur pengelolaan pengaduan}

Menurut Clinical Practice Guideline, yang dimaksudkan dengan 'standar' adalah keadaan ideal atau tingkat pencapaian tertinggi dan sempurna yang dipergunakan sebagai batas penerimaan minimal sedangkan di dalam bidang manajemen kata 'prosedur' dapat didefinisikan sebagai langkah-langkah pentahapan dan urutan-urutan pekerjaan dalam rangka mencapai tujuan secara efisien dan efektif. Dengan ini, dalam pengelolaan aplikasi pengaduan masyarakat tentu memiliki standar dan prosedur agar dapat berjalan dengan efektif dan efesien, hal ini berlaku pula untuk standar atau ciri-ciri pengaduan yang akan ditangani artinya lembaga terkait tidak akan memproses keluhan masyarakat apabila laporan yang masuk tidak sesuai dengan standar ketentuan. Pemerintah Pusat telah mengaturnya di dalam Peraturan Menteri Pendayagunaan Aparatur Negara dan Reformasi Birokrasi Nomor 3 Tahun 2015 tentang Road Map Pengembangan Sistem Pengelolaan Pelayanan Pengaduan Nasional yang telah secara khusus dan terstruktur mengatur tentang prosedur pengaduan pelayanan publik melalui aplikasi LAPOR. 


\subsubsection{Pentahapan Pengelolaan Pengaduan}

Menurut Kamus Besar Bahasa Indonesia yang dimaksud dengan pentahapan atau tahap ialah bagian dari sesuatu yang memiliki awal dan akhir atau terdapat urutan dan tingkatan. Dalam hal ini pentahapan yang dimaksud ialah tingkatan lembaga yang menerima laporan dari palapor atau masyarakat. Proses pengaduan yang ada berawal dari masyarakat mengadu kepada pemerintah bisa berupa saran, pertanyaan atau keluhan, kemudian masyarakat dapat mengadu melalui aplikasi Layanan Aspirasi dan Pengaduan Online Rakyat (LAPOR) yang sudah tersedia di Playstore/Appstore. Meskipun sistem ini terpusat dan sederhana tetapi dalam pengimplementasiannya terdapat permasalahan lain yaitu lambannya proses yang dilalui seperti terjadinya keterlambatan respon dari unit kerja terkait dengan keluhan dari masyarakat yang masuk ke dalam sistem, serta terkadang pula terjadi error system yang memakan waktu berhari-hari dengan menyebabkan keterlambatan dalam merespon keluhan atau laporan dari masyarakat

\subsubsection{Tindak Lanjut dan Kurun Waktu Penyelesaian Pengaduan}

Menurut Cambridge Dictionary, tindaklanjut ialah "A further action connected with something that happened before" yang artinya sebuah tindakan selanjutnya terkait dengan sesuatu yang terjadi sebelumnya, selain itu tindak lanjut juga dilaksanakan sebagai alat ukur dalam menilai pemeriksaan yang telah djalankan. Dalam pelaksanaan aplikasi LAPOR, setiap laporan yang masuk ke dalam sistem akan ditelusuri dahulu kebenarannya menggunakan standar yang ada, apabila laporan sudah sesuai maka laporan berhak untuk ditindaklanjuti dan sesuai kurun waktu yang telah ditentukan. Dalam hal ini dapat disimpulkan bahwa implementasi Electronic Governance melalui aplikasi LAPOR dalam hal standar dan prosedur sudah terimplementasikan dengan baik, sebaliknya dengan indikor kedua yaitu kurun waktu dan tindaklanjut yang masih belum terimplementasikan dengan baik.

\subsection{Integrasi dalam Pelaksanaan Aplikasi LAPOR di Kabupaten Karawang}

Integrasi ialah pengukuran terhadap tingkat kemampuan suatu organisasi untuk mengadakan sosialisasi dan pengembangan komunikasi dengan berbagai macam organisasi lainnya atau dapat dikatakan bahwa integrasi menyangkut 
pula dengan proses sosialisasi (Duncan yang dikutip Steers (1985:53). Integrasi dapat di definisikan pembauran hingga menjadi satu-kesatuan yang utuh, sehingga untuk mencapai sebuah keefektivas diperlukan kerjasama antara satu pihak dan pihak lain, baik kerjasama dalam bentuk horizontal (pemerintah dengan lembaga setara) maupun kerjasama dalam bentuk vertikal (pemerintah dengan masyarakat).

\subsubsection{Sosialisasi Program Aplikasi Layanan Aspirasi dan Pengaduan Online Rakyat (LAPOR) di Kabupaten Karawang}

Sosialisasi merupakan tindakan atau kemampuan penyelenggara dalam menyebarluaskan informasi mengenai pelaksanaan program agar dapat tersampaikan kepada masyarakat, bentuk sosialisasi ada dua (2) macam yaitu sosialisasi langsung dan tidak langsung. Sosialisasi langsung ialah sosialisasi yang dilakukan secara tatap muka dengan masyarakat di dalam sebuah kegiatan formal maupun non-formal sedangkan sosialisasi tidak langsung ialah sosialisasi yang dilakukan oleh penyelenggara melalui media massa dan media elektronik. Kegiatan sosialisasi ini dilakukan dengan tujuan agar informasi terkait program aplikasi LAPOR tersampaikan kepada masyarakat. Berdasarkan hasil wawancara yang telah dilakukan dengan para informan diatas, peneliti melihat bahwa baik Dinas Komunikasi dan Informatika Kabupaten Karawang atau Organisasi Pemerintah Daerah belum mensosialisasikan dengan optimal kepada masyarakat, hal ini pula yang menjadi penyebab belum efektifnya pelaksanaan aplikasi LAPOR di Kabupaten Karawang.

\subsubsection{Koordinasi dan Komunikasi instansi terkait pengaduan masyarakat}

Komunikasi memiliki peranan sentral, proses dan pola komunikasi merupakan sarana yang diperlukan untuk mengkoordinasi dan mengarahkan kegiatan tenaga kerja ke tujuan dan sasaran organisasi, sebagaimana dikemukakan oleh Barnard (1938) ia mengatakan "Dalam teori organisasi yang lengkap, komunikasi menduduki tempat paling sentral karena struktur, luasnya, dan lingkup organisasi hampir sepenuhnya ditentukan oleh teknik komunikasinya". Dalam pengelolaan pengaduan, komunikasi sangat penting dalam menghasilkan

koordinasi yang baik, hal ini dilakukan oleh Dinas Komunikasi dan Informatika 
Kabupaten Karawang dalam melakukan koordinasi dengan dinas terkait atau dinas yang menjadi tujuan dari keluhan yang terjadi di masyarakat. Berdasarkan hasil wawancara yang dilakukan oleh para informan diatas dapat disimpulkan bahwa dalam hal koordinasi dan komunikasi antara instansi berjalan dengan efektif karena koordinasi dilakukan dalam bentuk pertemuan maupun dengan mengirim pesan atau surat.

\subsection{Adaptasi dalam Pelaksanaan Aplikasi LAPOR di Kabupaten Karawang}

Adaptasi menurut Duncan ialah kemampuan organisasi untuk menyesuaikan diri dengan lingkungannya dan selalu ditekankan keharusan untuk selalu siap menyesuaikan dengan perubahan dalam lingkungan.

\subsubsection{Pelatihan Guna Meningkatkan Kemampuan}

Dalam mengelola sebuah aplikasi diperlukan bekal kemampuan untuk para tenaga kerja administrasi pengelolaan aplikasi LAPOR dengan tujuan agar meningkatkan kemampuan dan wawasan sumber daya manusia dalam penyelenggaraan dan pengelolaan aplikasi LAPOR. Berdasarkan informasi dari berita online dan berdasarkan hasil wawancara yang telah dilakukan bahwa terdapat pelatihan yang diadakan oleh Kementerian Aparatur Negara dan Reformasi Birokrasi yang berlokasi di Jakarta dengan mengumpulkan admin instansi se-Indonesia, dan terdapat pula pelatihan yang diadakan oleh Dinas Komunikasi dan Informasi Kabupaten Karawang dengan dihadiri oleh unit kerja terkait yang berlokasi di Kabupaten Karawang.

\subsubsection{Pengisian Tenaga Kerja}

Sumber daya manusia merupakan hal yang penting dalam menjalankan program atau kegiatan, karena apabila dilengkapi SDM yang memadai dan ahli sesuai dengan bidangnya maka akan menjadikan program atau kegiatan tersebut berjalan efektif. Berdasarkan hasil wawancara yang telah dilakukan dengan informan di atas, peneliti melihat bahwa adaptasi dalam hal pengisian tenaga kerja belum efektif karena masih sangat kurang atau sangat sedikit tenaga kerja yang ada sehingga dapat mengakibatkan lambannya proses pengelolaan keluhan dari masyarakat melalui aplikasi LAPOR. 


\section{Penutup \\ Kesimpulan}

Berdasarkan hasil penelitian yang berjudul pelaksanaan aplikasi Layanan Aspirasi dan Pengaduan Online Rakyat (LAPOR) di Kabupaten Karawang, dapat disimpulkan bahwa:

1. Pencapaian Tujuan dalam pelaksanaan aplikasi LAPOR di Kabupaten Karawang sudah berjalan sesuai dengan tujuan atau sasaran yang ingin dicapai, begitu pula dengan indikator pertama dan kedua yaitu standar dan prosedur pengaduan penelitian, dan pentahapan pengelolaan penelitian. Akan tetapi terdapat bentuk ketidakefektifan dengan indikator ketiga yaitu tindaklanjut dan kurun waktu penyelesaian pengaduan.

2. Integrasi dalam pelaksanaan aplikasi LAPOR di Kabupaten Karawang sudah cukup efektif dalam pelaksanaan koordinasi dan komunikasi. Akan tetapi, tidak optimal dalam mensosialisasikan aplikasi tersebut. Fokus sosialisasi Dinas Komunikasi dan Informatika Kabupaten Karawang hanya kepada Organisasi Perangkat Daerah (OPD) saja, sedangkan masyarakat belum pernah mendapatkan sosialisasi langsung baik dari dinas terkait maupun dari OPD yang ada.

3. Adaptasi dalam pelaksanaan aplikasi LAPOR mencakup 2 indikator yaitu peningkatan kemampuan, dan pengisian tenaga kerja. Dalam indikator peningkatan kemampuan dapat disimpulkan bahwa terdapat kegiatan pelatihan untuk tenaga kerja yang mengelola aplikasi LAPOR, dan hal tersebut sudah dilakukan baik oleh pemerintah pusat dan pemerintah daerah. Akan tetapi terkait indikator kedua yaitu pengisian tenaga kerja dapat disimpulkan bahwa hal tersebut belum efektif karena masih sangat kurang atau sangat sedikit tenaga kerja yang ada sehingga dapat mengakibatkan lambannya proses pengelolaan keluhan dari masyarakat melalui aplikasi LAPOR.

\section{Saran}

\section{Saran Praktis}

Berdasarkan kesimpulan di atas, peneliti mengajukan bebeapa saran, diantaranya : 
Pratiwi, Mayasari, Febriantin Implementasi Electronic Governance... | 95

1. Dalam menindaklanjuti keluhan masyarakat harusnya Dinas Komunikasi dan Informatika Kabupaten Karawang dapat menindaklanjuti keluhan dari masyarakat Kabupaten Karawang sesuai dengan ketentuan dari Peraturan Menteri Pendayagunaan Aparatur Negara dan Reformasi Birokrasi No. 3 Tahun 2015 tentang Roadmap Pengembangan Sistem Pengelolaan pengaduan Pelayananan Publik Nasional serta Peraturan Daerah Kabupaten Karawang No. 16 Tahun 2016.

2. Dinas Komunikasi dan Informatika Kabupaten Karawang harus lebih giat lagi mensosialisasikan aplikasi LAPOR kepada masyarakat baik melalui minggon desa, minggon kecamatan ataupun kunjungan ke kampus atau ke sekolah. Agar program ini dapat tepat sasaran dan manfaatnya dirasakan dengan baik oleh masyarakat Kabupaten Karawang.

3. Dinas Komunikasi dan Informatika Kabupaten Karawang perlu menambahkan tenaga kerja di bidang admin instansi karena apabila hanya terdapat satu tenaga kerja di bidang admin instansi hal ini dapat mempengaruhi aplikasi LAPOR bagi masyarakat Kabupaten Karawang.

Saran Akademik

Peneliti juga mempunyai saran bagi peneliti selanjutnya yaitu penelitian ini dapat dijadikan bahan referensi serta sebagai bahan pertimbangan untuk lebih memperdalam dan menyempurnakan penelitian selanjutnya dengan mempertimbangkan dan membandingkan perkembangan waktu dan evaluasi kebijakan yang baru. Peneliti juga menyarankan untuk memperdalam objek apa yang akan diteliti, baik isi berita yang ada, media yang akan di teliti, teori yang akan digunakan, serta model penelitian yang akan di gunakan karena itu semua akan mempengaruhi hasil penelitian nanti. 
96 Pratiwi, Mayasari, Febriantin Implementasi Electronic Governance...

\section{DAFTAR PUSATAKA}

\section{Buku:}

Harbani, P. (2014). Teori Administrasi Publik. Bandung: CV. Alfabeta.

Holmes. (2004). Electronic Goverment (Strategi Pembangunan dan

Pengembangan Sistem Pelayanan Publik Berbasis Teknologi Digital). Yogyakarta.

Kurniawan, A. (2005). Transformasi Pelayanan Publik. Yogyakarta.

Pasolong, H. (2014). Teori Administrasi Publik. Bandung: CV. Alfabeta.

Ricardus Eko, I. (2004). Electronic Governement (Strategi Pembangunan dan Pengembangan Sistem Pelayanan Publik Berbasis Teknologi Digital). Yogyakarta: ANJI.

Sujata, A. (2002). Masa Lalu, Sekarang, dan Masa Mendatang. Jakarta: Komisi Ombudsman Nasional.

\section{Jurnal:}

Advisor, T. C. (2001). The California Legislature's Nonpartisan Fiscal and Policy Advisor.

McLean, D. (2003). Model of Information System Success: A Ten-Years Update. 19.

Sorin, K. (2003). Cost-Benefit Analysis of e-government Investments.

Mursalim, S. W. (2018). Analisis Manajemen Pengaduan Sistem Layanan Aspirasi Pengaduan. 15.

\section{Skripsi:}

Sitoresmi, S. (2013). Efektivitas Sistem Informasi Layanan Aspirasi dan Pengaduan Online Rakyat (LAPOR!) Pada Unit Kerja Presiden Bidang Pengawasan dan Pengendalian Pembangunan (UKP4).

\section{Dokumen:}

Kementerian Pendayagunaan Aparatur Negara dan Reformasi Birokrasi Nomor 3 Tahun 2015 tentang Road Map Pengembangan Sistem Pengelolaan Pengaduan Pelayanan Publik Nasional.

Peraturan Pemerintah Nomor 101 Tahun 2000.

Peraturan Daerah Kabupaten Karawang Nomor 14 Tahun 2017 tentang Keterbukaan Informasi. 
Peraturan Presiden Nomor 76 Tahun 2013 tentang Pengelolaan Pengaduan Pelayanan Publik.

Pertauran Daerah Kabupaten Karawang Nomor 16 Tahun 2018 tentang Sistem Pemerintah Berbasis Elektronik.

Undang-Undang Nomor 25 Tahun 2009 tentang Pelayanan Publik. 